\title{
Studies on leakage of enzymes from washed bull and ram spermatozoa
}

\author{
O. A. Osinowo* \\ A.R.C. Institute of Animal Physiology, Animal Research Station, 307 Huntingdon Road, \\ Cambridge CB3 OJQ, U.K.
}

\begin{abstract}
Summary. Washing of bull and ram spermatozoa resulted in significant losses of lactic dehydrogenase (LDH) and glucose phosphate isomerase (GPI) from the cell suspensions. Re-suspension of washed bull spermatozoa caused an immediate release of enzymes from the cells. Preincubation of washed ram spermatozoa with $0.025 \%$ formaldehyde increased GPI levels but decreased LDH concentration in the extracellular fluid while hexokinase release was unaffected. Varying the incubation temperature between 20 and $37^{\circ} \mathrm{C}$ affected extracellular LDH and GPI levels. It is suggested that enzyme release from spermatozoa may occur in the absence of any apparent cellular damage.
\end{abstract}

\section{Introduction}

Extracellular enzyme activities are sometimes used to assess cell membrane damage during in-vitro storage of spermatozoa (Crabo, Bower, Brown, Graham \& Pace, 1970; Bower, Crabo, Pace \& Graham, 1973; Foulkes \& Watson, 1975). Some attempts have also been made to relate acrosomal enzyme release with sperm capacitation (Austin, 1960; Allison \& Hartree, 1970; Rogers \& Morton, 1973). Generally, the pattern of enzyme release by mammalian cells is complex (Schmidt \& Schmidt, 1974) and differences between pathological and physiological release are unclear.

Graham, Schmehl \& Maki-Laurila (1970) showed that the activities of glutamic oxaloacetic transaminase, lactic dehydrogenase, hyaluronidase, acid phosphatase and alkaline phosphatase in the extracellular fluids of bull, boar, stallion and turkey semen increased after deep freezing in proportion to the extent of cellular damage. However, Kurilo (1972) reported that the extracellular activities of glucose phosphate isomerase and alkaline and acid phosphatases in boar semen did not increase following deep freezing, while aldolase increased more than 2-fold. The release of certain enzymes may therefore be poorly correlated with cellular damage. Crabo et al. (1970) reported that dilution of semen caused leakage of glutamic oxaloacetic transaminase from spermatozoa, with time, temperature and diluent composition being implicated as important factors. However, cytoplasmic droplets and spermatozoa contain enzymes which leak into the extracellular medium during dilution, cooling or freezing (Harrison \& White, 1972a, b). In the present study, the effect of washing on the total enzyme activities remaining in the sperm suspensions, leakage of enzymes during re-suspension and incubation, and the effects of incubation temperature and preincubation of spermatozoa with formaldehyde were examined.

* Present address: Department of Animal Reproduction, National Animal Production Research InstituteAhmadu Bello University, Shika, Zaria, Nigeria. 


\section{Materials and Methods}

\section{Sperm washing, re-suspension and incubation}

The sperm washing method of Harrison (1976) was used. Freshly collected bull semen was diluted 2- to 5-fold with an artificial medium composed of 2 mM-Hepes (N-2 hydroxyethyl piperazine- $\mathrm{N}^{\prime}$-2-ethanesulphonic acid), $10 \mathrm{~mm}$-glucose, 2 mM-disodium hydrogen phosphate dodecahydrate, $2.5 \mathrm{~mm}$-potassium hydroxide, $34 \mathrm{~mm}$-sodium chloride and $100 \mathrm{~mm}$-sucrose, adjusted to $\mathrm{pH} 7.5$ with $1 \mathrm{~N}-\mathrm{NaOH}$. The sperm washing fluid was made up by dissolving ficoll (mol wt $\sim 400000 ; 7.5 \% \mathrm{w} / \mathrm{v}$ ) in the artificial medium. The diluted semen $(1 \mathrm{ml})$ was layered on $5 \mathrm{ml}$ washing fluid contained in a $10 \mathrm{ml}$ graduated plastic centrifuge tube. After centrifugation (600 $\mathrm{g}$ for $5 \mathrm{~min}$ and $1000 \mathrm{~g}$ for $15 \mathrm{~min}$ ) the top layers were quickly aspirated, leaving the bottom $1 \mathrm{ml}$ portion consisting of packed spermatozoa and a small layer of washing fluid. This portion was gently mixed with a Pasteur pipette and transferred into a test tube where the spermatozoa were re-suspended with the artificial medium to a total volume of $4 \mathrm{ml}$ and incubated at 20,30 or $37^{\circ} \mathrm{C}$ for different periods. For ram semen, the initial dilution was with phosphate-buffered saline (Dott, 1975) (PBS), pH 7.2. The washing fluid was the same as for bull semen but aspiration of fluid after washing was more complete, leaving only the sperm pellet at the bottom of the centrifuge tube. The washed ram spermatozoa were re-suspended to a total volume of $1 \mathrm{ml}$ with PBS before incubation.

\section{Determination of extracellular and total enzyme activities}

Extracellular enzyme activities were determined in the supernatant obtained after removal of the spermatozoa by centrifugation at $1000 \mathrm{~g}$ for $15 \mathrm{~min}$. Total enzyme activities were determined in sperm homogenates obtained by sonication of $4 \mathrm{ml}$ sperm suspensions at $50 \mathrm{~W}$ for $15 \mathrm{sec}$ (Kerry's Ultrasonic Disruptor K100). Enzyme assays were carried out using a recording spectrophotometer (Unicam SP800) at $37^{\circ} \mathrm{C}$ and $340 \mathrm{~nm}$. The sperm homogenization method and enzyme assays were based on the methods previously described in detail by Harrison (1971). Final concentrations of the constituents of the assay systems were as follows: lactic dehydrogenase (EC 1.1.1.27)- $100 \mathrm{~mm}$-Tris- $\mathrm{HCl}, 1 \mathrm{~mm}$-EDTA, $1 \mathrm{~mm}$-2-mercaptoethanol, $2 \mathrm{mM}$-sodium pyruvate and $0.25 \mathrm{mM}-\mathrm{NADH}$; glucose phosphate isomerase (EC 5.3.1.9) $100 \mathrm{~mm}$-Tris-HCl, $1 \mathrm{~mm}$-EDTA, $1 \mathrm{mM}$-2-mercaptoethanol, $10 \mathrm{~mm}-\mathrm{MgCl}_{2}, 1 \mathrm{~mm}$-fructose 6-phosphate, $0.5 \mathrm{mM}-\mathrm{NADP}^{+}$and about 0.56 units of glucose 6-phosphate dehydrogenase $/ \mathrm{ml}$; hexokinase (EC 2.7.1.1)-100 mM-Tris-HCl, 1 mM-EDTA, 1 mM-2-mercaptoethanol,

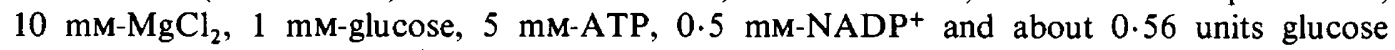
6-phosphate dehydrogenase $/ \mathrm{ml}$. All assays were carried out at $\mathrm{pH} 8.2$ in a total volume of $1 \mathrm{ml}$. The reaction was initiated by addition of a $20 \mu \mathrm{l}$ sample of supernatant or sperm homogenate to the pre-warmed assay mixture in $1 \mathrm{ml}$ cuvettes followed by rapid mixing and transfer to the spectrophotometer. The extinction was recorded automatically over a period of at least $2 \mathrm{~min}$, changes in absorbance being linear for $>5 \mathrm{~min}$. Extinction rates of blanks containing sample and assay mixtures but excluding substrates were negligible. Assays were carried out in duplicate and the mean values were used in the analyses. Sperm concentrations were determined by haemocytometer counts and enzyme activities were expressed in units per $10^{9}$ spermatozoa, 1 unit of enzyme activity being the conversion of $1 \mu \mathrm{mol}$ substrate per minute.

\section{Statistical analyses}

The effect of washing on total glucose phosphate isomerase and lactic dehydrogenase activities of spermatozoa suspensions and the effect of formaldehyde treatment on extracellular enzyme activities were tested using one-way analyses of variance. Two-way and three-way analyses of variance were used to test the treatment effects in comparisons involving more than one enzyme after log-transformation of the data. 


\section{Results}

\section{Enzyme activities of sperm suspensions before and after washing}

Since sperm washing involved the removal of seminal plasma and cytoplasmic droplets, the resulting sperm suspension would be expected to have lower glycolytic enzyme activities than the original semen. Enzyme activities in sperm suspensions before and after washing were therefore investigated.

About 33 and $57 \%$ respectively of the total lactic dehydrogenase (LDH) and glucose phosphate isomerase (GPI) activities initially present in a sample of bull semen were removed with the washing fluid in a preliminary experiment. Further investigations with bull semen revealed an unequal distribution of enzyme activities between different layers of the centrifuge tube immediately after the centrifugation step. The percentages of total LDH and GPI activities contained in the topmost $1 \mathrm{ml}$ (seminal plasma), intermediate $4 \mathrm{ml}$ (washing fluid) and bottom $1 \mathrm{ml}$ (spermatozoa plus some washing fluid) layers were 6.7 and $27.5 \%, 12.0$ and $24.8 \%$, and $81 \cdot 3$ and $47.7 \%$, respectively.

In 3 experiments with ram semen, mean total GPI activities ( \pm s.e.m.) in samples before and after washing were $49.97 \pm 10.21$ and $10.41 \pm 1.72$ units per $10^{9}$ spermatozoa respectively. Corresponding $\mathrm{LDH}$ activities of unwashed and washed samples were $58.78 \pm 9.56$ and $27.53 \pm 3.37$ units per $10^{9}$ spermatozoa respectively. Enzyme losses resulting from sperm washing were significant $(P<0.05)$.

\section{Leakage of enzymes from washed bull spermatozoa}

The relationships between intracellular and extracellular enzyme activities can be easily studied in washed sperm suspensions since the cell/medium boundary is distinct. Table 1 shows the results with washed bull spermatozoa suspended in an artificial medium and incubated at $37^{\circ} \mathrm{C}$. In general, extracellular values were greater than would be expected from contamination by residual activity from the washing fluid. Calculated maximum enzyme activities in the washing fluid, as percentages of the total activity, were $3.25 \%$ and $0.92 \%$ for GPI and LDH respectively, but percentages after washing and dilution of the samples ranged from 8.8 to $71.9 \%$ for GPI and from 2.2 to $5.6 \%$ for LDH. Enzyme leakage therefore occurred as a reaction of spermatozoa to dilution during the re-suspension step. Intracellular:extracellular enzyme activity ratios for LDH were consistently and significantly higher $(P<0.001)$ than the corresponding values for GPI.

Table 1. Mean \pm s.e.m. enzyme activities of washed bull spermatozoa assayed after incubation at $37^{\circ} \mathrm{C}$ for

$30 \mathrm{~min}$

\begin{tabular}{cccc}
\hline & & \multicolumn{2}{c}{$\begin{array}{c}\text { Enzyme activity } \\
\text { (units } / 10^{9} \text { spermatozoa) }\end{array}$} \\
\cline { 3 - 4 } Enzyme & $\begin{array}{c}\text { No. of } \\
\text { exps }\end{array}$ & Extracellular & Total \\
\hline GPI & 3 & $1.30 \pm 0.18$ & $9.41 \pm 0.99$ \\
LDH & 3 & $0.39 \pm 0.13$ & $8.22 \pm 0.62$ \\
\hline
\end{tabular}

\section{Extracellular enzyme activities in washed ram sperm suspensions}

Effects of incubation period and temperature. Suspensions of washed ram spermatozoa were incubated at 20,30 or $37^{\circ} \mathrm{C}$ and determinations of the extracellular activity were made after incubation for $30,60,120$ and $240 \mathrm{~min}$. In the 3 experiments carried out, sperm concentrations 
during incubation varied from 0.539 to $0.6973 \times 10^{9} \mathrm{cells} / \mathrm{ml}$, and mean \pm s.e.m. total activity was $10.45 \pm 1.38$ and $27.70 \pm 2.77$ units per $10^{9}$ spermatozoa for GPI and LDH respectively.

For both enzymes, extracellular activity increased significantly with time $(P<0.001$, Table 2). In relative terms, leakage increased from 14.4 to $19.6 \%$ for GPI and from 0.4 to $1 \cdot 1 \%$ for LDH between 30 and $240 \mathrm{~min}$. There was a significant enzyme $\times$ temperature interaction $(P<0.001$; Table 2 ) which was due to the fact that extracellular activity was highest for GPI but lowest for $\mathrm{LDH}$ at $20^{\circ} \mathrm{C}$. Furthermore, while extracellular $\mathrm{LDH}$ increased with each increase in temperature, extracellular GPI appeared lowest at $30^{\circ} \mathrm{C}$.

Table 2. Effects of incubation period and temperature on the extracellular enzyme activities of washed ram spermatozoa*

\begin{tabular}{cccc}
\hline & & \multicolumn{2}{c}{$\begin{array}{c}\text { Extracellular enzyme activities } \\
\text { (units } / 10^{9} \text { spermatozoa) }\end{array}$} \\
\cline { 3 - 4 } $\begin{array}{c}\text { Incubation } \\
\text { temperature }\left({ }^{\circ} \mathrm{C}\right)\end{array}$ & $\begin{array}{c}\text { Incubation } \\
\text { period (min) }\end{array}$ & $\mathrm{GPI}$ & $\mathrm{LDH}$ \\
\hline 20 & 30 & $1.49 \pm 0.04$ & $0.12 \pm 0.05$ \\
& 60 & $1.74 \pm 0.14$ & $0.07 \pm 0.02$ \\
& 120 & $1.89 \pm 0.21$ & $0.11 \pm 0.02$ \\
& 240 & $2.40 \pm 0.26$ & $0.13 \pm 0.02$ \\
30 & 30 & $1.52 \pm 0.05$ & $0.07 \pm 0.02$ \\
& 60 & $1.31 \pm 0.14$ & $0.11 \pm 0.03$ \\
& 120 & $1.67 \pm 0.03$ & $0.19 \pm 0.04$ \\
& 240 & $1.87 \pm 0.11$ & $0.27 \pm 0.03$ \\
& 30 & $1.51 \pm 0.08$ & $0.13 \pm 0.03$ \\
& 60 & $1.56 \pm 0.04$ & $0.20 \pm 0.03$ \\
& 120 & $1.71 \pm 0.09$ & $0.31 \pm 0.01$ \\
& 240 & $1.87 \pm 0.16$ & $0.48 \pm 0.04$ \\
\hline
\end{tabular}

Values are mean \pm s.e.m. of 3 samples.

* Effect of incubation period, $P<0.001$; enzyme $\times$ temperature interaction, $P<0.001$.

\section{Effect offormaldehyde}

Washed ram spermatozoa were re-suspended in PBS or PBS containing $0.025 \%$ formaldehyde and incubated at room temperature $\left(20^{\circ} \mathrm{C}\right)$ for $15 \mathrm{~min}$. Samples were centrifuged at $1000 \mathrm{~g}$ for $15 \mathrm{~min}$ and the supernatant fractions were replaced with PBS without formaldehyde before incubation at 20,30 or $37^{\circ} \mathrm{C}$. Extracellular enzyme activities were determined in the samples after incubation for 30, 60, 120 and $240 \mathrm{~min}$. The results are presented in Table 3. Formaldehyde had an effect on extracellular GPI activity but not on extracellular hexokinase activity.

Table 3. Effect of formaldehyde on the extracellular enzyme activities of washed ram spermatozoa

\begin{tabular}{|c|c|c|c|c|c|c|}
\hline \multirow{3}{*}{$\begin{array}{l}\text { Incubation } \\
\text { temperature } \\
\left({ }^{\circ} \mathrm{C}\right)\end{array}$} & \multicolumn{6}{|c|}{ Extracellular enzyme activities (units/ $10^{9}$ spermatozoa) } \\
\hline & \multicolumn{2}{|c|}{ GPI } & \multicolumn{2}{|c|}{ LDH } & \multicolumn{2}{|c|}{$\mathrm{HK}$} \\
\hline & A & B & A & B & A & B \\
\hline 20 & $1.24 \pm 0.19$ & $2 \cdot 01 \pm 0 \cdot 10^{*}$ & $0.10 \pm 0.07$ & $0.08 \pm 0.12 \dagger$ & $0.04 \pm 0.01$ & $0.02=$ \\
\hline 30 & $0.93 \pm 0.07$ & $1.62 \pm 0.10^{*}$ & $0.29 \pm 0.05$ & $0.13 \pm 0.03 \dagger$ & $0.06 \pm 0.01$ & $0.04 \pm 0.01$ \\
\hline 37 & $0.92 \pm 0.04$ & $1.68 \pm 0.04^{*}$ & $0.29 \pm 0.05$ & $0.25 \pm 0.05$ & $0.05 \pm 0.01$ & $0.06 \pm 0.01$ \\
\hline
\end{tabular}

Values are means ( \pm s.e.m.) of $8(\mathrm{GPI}, \mathrm{LDH})$ or $4(\mathrm{HK})$ samples.

A: control, preincubated with PBS only; B: preincubated with PBS containing $0.025 \%$ formaldehyde.

${ }^{*} P<0.001$ compared with control value.

$\dagger P<0.05$ compared with control value. 


\section{Discussion}

The results of the present study showed clearly that significant amounts of LDH and GPI in semen were lost to spermatozoa as a result of washing. This was probably due to the removal of seminal plasma and cytoplasmic droplets which contain enzymes (Harrison \& White, 1972a, b). Enzymes leaked from washed spermatozoa under conditions which seemed to preclude cellular damage, and the extent of leakage differed between enzymes. Changes in temperature and contact of spermatozoa with formaldehyde had varied effects on enzyme leakage.

Enzyme losses occurring as a result of sperm washing are usually unreported. However, the detrimental effects of washing on the metabolism, morphology and motility of mammalian spermatozoa are well documented (Rothschild, 1959; Dott \& Walton, 1960; Wales \& Wallace, 1965; Jones \& Holt, 1974; Harrison, Dott \& Foster, 1978). The altered metabolic pattern of washed spermatozoa could be explained by the substrate (Wales \& Wallace, 1965), enzyme and coenzyme losses sustained during washing. Other effects of washing, such as agglutination, increased eosin uptake and depressed motility (Dott \& Walton, 1960), as well as ultrastructural alterations (Jones \& Holt, 1974), appear to be physical manifestations of effects of protein leakage from cells. Spermatozoa therefore need to be washed to replace the very complex seminal plasma with a simpler medium while keeping leakage of intracellular constituents minimal. In this regard, optimum conditions for sperm washing in relation to the osmotic pressure, $\mathrm{pH}$, ionic strength, volume and temperature of the washing fluid remain largely unknown (but see Harrison \& White, 1972a; Harrison, 1976).

The leakage of enzymes associated with the re-suspension of washed spermatozoa as found in the present study is in agreement with previous reports (Crabo et al., 1970; Harrison \& White, 1972b; Bower et al., 1973). This release was completed in a few minutes, faster than could be determined by the methods used in the present investigation. There are similarities between sperm enzyme release as a result of dilution and the release of enzymes by osmotic shock from exponentially growing Escherichia coli for which the process was found to be completed within about $1 \mathrm{~min}$ (Nossal \& Heppel, 1966). Leakage of intracellular material during dilution could be a mechanism used to eliminate osmotic differences between intracellular and extracellular fluids, thereby controlling cell volume. If this is the case, then the osmotic pressure difference between the two fluids as well as the concentration of spermatozoa would seem to be critical factors determining the extent of leakage, although these have not been investigated. Cell damage could result from a large osmotic differential, especially when the sperm concentration is low.

The observed effect of temperature on enzyme leakage pattern may be due to its effect on diffusion processes generally, and to its effect on membrane structure. For example, the membrane may become less fluid as the temperature decreases (Singer, 1974), thereby altering its permeability characteristics. The temperature range $\left(20-37^{\circ} \mathrm{C}\right)$ used in the present investigation was chosen to avoid leakage due to cold shock (Harrison \& White, 1972b). The effect of formaldehyde on leakage patterns was probably due to modification of protein molecules (Herriott, 1947), for example by altering their charge distributions, although effects on the membrane and on metabolism cannot be ruled out.

The results presented in this paper indicate that enzyme leakage may not necessarily be an indication of cellular damage.

I thank Dr H. M. Dott and Dr Harrison for their advice and Mr G. Foster for technical assistance. The study was conducted during a felowship awarded by the Association of Commonwealth Universities. 


\section{References}

Allison, A.C. \& Hartree, E.F. (1970) Lysosomal enzymes in the acrosome and their possible role in fertilization. J. Reprod. Fert. 21, 501-515.

Austin, C.R. (1960) Capacitation and the release of hyaluronidase from spermatozoa. J. Reprod. Fert. 1 , $310-311$.

Bower, R.E., Jr, Crabo, B.G., Pace, M.M. \& Graham, E.F. (1973) Effects of dilution and glycerol on the release of glutamic-oxaloacetic transaminase (GOT) from boar spermatozoa. J. Anim. Sci. 36, 319-324.

Brown, K.I., Crabo, B.G., Graham, E.F. \& Pace, M.M. (1971) Some factors affecting loss of intracellular enzymes from spermatozoa. Cryobiology 8, 220224.

Crabo, B.G., Bower, R.E., Brown, K.I., Graham, E.F. \& Pace, M.M. (1970) Extracellular glutamicoxaloacetic transaminase as a measure of membrane injury in spermatozoa during treatment. In Current Problems in Fertility, pp. 33-38. Eds A. Ingelmansundberg \& N. O. Lundell. Plenum Press, New York.

Dott, H.M. (1975) The estimation of the proportion of motile bull spermatozoa in various diluents and a comparison with the proportion eosinophilic. $J$. Reprod. Fert. 45, 47-55.

Dott, H.M. \& Walton, A. (1960) Effects of dilution and washing on ram spermatozoa studied by the flow dialy sis technique. J. Reprod. Fert. 1, 350-367.

Foulkes, J.A. \& Watson, F.A. (1975) Hyaluronidase activity in seminal plasma as a method of assessing bull sperm integrity. J. Reprod. Fert. 43, 349-353.

Graham, E.F., Schmehl, M.K.L. \& Maki-Laurila, M. (1970) Some physical and chemical methods of evaluating semen. Proc. 3rd Tech. Conf. Anim. Reprod.\& A.I., N.A.A.B., pp. 1-6.

Harrison, R.A.P. (1971) Glycolytic enzymes in mammalian spermatozoa: activities and stabilities of hexokinase and phosphofructokinase in various fractions from sperm homogenates. Biochem. $J .124$, 741-750.

Harrison, R.A.P. (1976) A highly efficient method for washing mammalian spermatozoa. J. Reprod. Fert. 48, 347-353.

Harrison, R.A.P. \& White, I.G. (1972a) Some methods for washing spermatozoa from bull, boar and ram: a comparison using biochemical and other criteria. $J$. Reprod. Fert. 29, 271-284.

Harrison, R.A.P. \& White, I.G. (1972b) Glycolytic enzymes in the spermatozoa and cytoplasmic droplets of bull, boar and ram, and their leakage after shock. J. Reprod. Fert. 30, 105-115.

Harrison, R.A.P., Dott, H.M. \& Foster, G.C. (1978) Effect of ionic strength, serum albumin and other macromolecules on the maintenance of motility and the surface of mammalian spermatozoa in a simple medium. J. Reprod. Fert. 52, 65-73.

Herriott, R.M. (1947) Reactions of native proteins with chemical reagents. Adv. Prot. Chem. 3, 169-225.

Jones, R.C. \& Holt, W.V. (1974) The effects of washing on the ultrastructure and cytochemistry of ram spermatozoa. J. Reprod. Fert. 41, 159-167.

Kurilo, J.G. (1972) The influence of the dilution and freezing of boar semen on the activity of some enzymes of carbohydrate-phosphate metabolism and sperm survival. Proc. 8th Int. Congr. Anim. Reprod. \& A. I., Munich, 2, 1668.

Nossal, N.G. \& Heppel, L.A. (1966) The release of enzymes by osmotic shock from Escherichia coli in exponential phase. J. Biol. Chem. 241, 3055-3062.

Rogers, B.J. \& Morton, B.E. (1973) The release of hyaluronidase from capacitating hamster spermatozoa. J. Reprod. Fert. 35, 477-487.

Rothschild, Lord (1959) Anaerobic heat production of bull spermatozoa. II. The effects of changes in the colligative and other properties of the suspending medium. Proc. R. Soc. B 151, 1-22.

Schmidt, E. \& Schmidt, F.W. (1974) The importance of enzymatic analysis in medicine: principles. In Methods of Enzymatic Analysis, 2nd English edn, vol. 1, pp. 6-14. Ed. H. U. Bergmeyer. Verlag Chemie, Weinheim.

Singer, S.J. (1974) Molecular biology of cellular membranes, with applications to immunology. $A d v$. Immunol. 19, 1-66.

Wales, R.G. \& Wallace, J.C. (1965) Effects of washing on the metabolism of bull spermatozoa. J. Reprod. Fert. 9, 261-263. 